\title{
Pengaruh Model Inquiry Training Terhadap Hasil Belajar Siswa Pada Materi Pokok Elastisitas dan Hukum Hooke
}

\author{
Benni S.M Sinaga ${ }^{1 *}$ dan Sondang R. Manurung ${ }^{2}$ \\ 1,2 Jurusan Fisika FMIPA Universitas Negeri Medan \\ ${ }^{*}$ E-mail: bennisinaga@gmail.com
}

\begin{abstract}
Abstrak
Penelitian ini bertujuan untuk mengetahui pengaruh model pembelajaran inquiry training terhadap hasil belajar siswa pada materi elastisitas dan hukum hooke. Jenis penelitian yaitu quasi experiment. Populasi dalam penelitian adalah seluruh siswa kelas XI Semester I SMA Negeri 1 Parbuluan yang terdiri dari empat kelas MIA. Sampel penelitian yaitu kelas XI MIA-1 sebagai kelas eksperimen dan kelas XI MIA-2 sebagai kelas kontrol, masingmasing berjumlah 35 orang yang ditentukan dengan cara cluster random sampling. Instrumen yang digunakan adalah tes hasil belajar. Berdasarkan hasil penelitian diperoleh nilai rata-rata pretes kelas eksperimen 32,00 dan nilai rata-rata pretes kelas kontrol 28,37. Nilai postes di kelas eksperimen memperoleh nilai rata-rata 64,57 dan kelas kontrol 55,62. Berdasarkan hasil analisis uji t disimpulkan bahwa ada perbedaan akibat pengaruh model pembelajaran inquiry training terhadap hasil belajar siswa pada materi elastisitas dan hukum hooke di kelas XI semester I SMA Negeri 1 Parbuluan, dari T.P. 2019/2020.
\end{abstract}

Kata kunci: model inquiry training, hasil belajar, aktivitas

\begin{abstract}
This study aims to determine the effect of the inquiry training learning model on student learning outcomes on elasticity and Hooke's law. This type of research is a quasi-experiment. The population in the study were all students of class XI Semester I SMA Negeri 1 Parbuluan which consisted of four MIA classes. The research sample was class XI MIA-1 as the experimental class and class XI MIA-2 as the control class, each of which totaled 35 people who were determined using cluster random sampling. The instrument used was a learning outcome test. Based on the results of the study, the pretest average value for the experimental class was 32.00 and the pretest average value for the control class was 28.37. The post-test score in the experimental class obtained an average value of 64.57 and the control class was 55.62. Based on the results of the t-test analysis, it is concluded that there is a difference due to the influence of the inquiry training learning model on student learning outcomes on elasticity and Hooke law in class XI semester I SMA Negeri 1 Parbuluan, from 2019/2020 academic year.
\end{abstract}

Keywords: inquiry training model, learning outcomes, activities

Article History: Received: 14 Oktober 2020

Accepted: 6 November 2020

Revised : 6 November 2020

Published: 20 November 2020

How to cite: Sinaga, B.S.M \& Manurung, S.. (2020). Pengaruh Model Inquiry Training Terhadap Hasil Belajar Siswa Pada Materi Pokok Elastisitas dan Hukum Hooke, 1(2). pp. 124 - 130. Retrieved from http://jurnal.fkip.unmul.ac.id/index.php/JLPF

Copyright (C) November 2020, Jurnal Literasi Pendidikan Fisika 


\section{PENDAHULUAN}

Pendidikan merupakan kebutuhan yang penting bagi setiap manusia. Tanpa pendidikan seseorang akan sulit untuk menyesuaikan diri dengan lingkungan dan tidak dapat berfungsi maksimal dalam kehidupan masyarakat. IImu pengetahuan dan teknologi berkembang pesat dan memunculkan tuntunan baru dalam segala aspek kehidupan termasuk dalam sistem pendidikan. Berbagai cara atau metode baru yang telah diperkenalkan serta digunakan supaya pembelajaran menjadi lebih bermakna. Undang-Undang No.20 Tahun 2003 tentang Sistem Pendidikan Nasional menyatakan bahwa Pendidikan adalah usaha sadar dan terencana untuk mewujudkan suasana belajar dan proses pembelajaran agar peserta didik secara aktif mengembangkan potensi dirinya untuk memiliki kekuatan spiritual keagamaan, pengendalian diri, kepribadian, kecerdasan, akhlak mulia, serta keterampilan yang diperlukan dirinya, masyarakat, bangsa dan negara.

Pendidikan yang berkualitas akan berpengaruh pada kemajuan berbagai bidang, akan tetapi salah satu persoalan besar yang dihadapi bangsa indonesia saat ini adalah rendahnya kualitas pendidikan. Rendahnya kualitas pendidikan tersebut disebabkan oleh banyak faktor, salah satunya mengenai proses pembelajaran yang berkaitan dengan pemilihan model. Pada proses pembelajaran, anak kurang didorong untuk mengembangkan kemampuan anak untuk menghafal informasi, otak anak dipaksa untuk mengingat dan menimbun berbagai informasi tanpa dituntut untuk memahami informasi yang diingatnya itu untuk meghubungkannya dengan kehidupan seharihari (Sanjaya, 2011).

Masalah utama dalam pendidikan dewasa ini adalah masih rendahnya daya serap peserta didik. Hal ini tampak dari rata-rata hasil belajar peserta didik yang senantiasa masih memprihatinkan. Prestasi ini tentunya merupakan hasil kondisi pembelajaran yang masih bersifat konvensional dan tidak menyentuh ranah dimensi didik itu sendiri, yaitu bagaimana sebenarnya belajar, dalam arti yang lebih substansial bahwa proses pembelajaran hingga dewasa ini masih memberikan akses bagi anak didik untuk berkembang secara mandiri melalui penemuan dalam proses berpikirnya (Wahyuni dan Sipapaga, 2015).

Rendahnya daya serap peserta didik tidak lepas dari permasalahan-permasalahan yang ditemui dalam proses pembelajaran. Salah satu contohnya adalah ketika siswa mengalami kesulitan dalam belajar. Kesulitan belajar merupakan salah satu gejala yang ditandai dengan berbagai tingkah laku yang berlatar belakang dalam diri maupun di luar diri siswa. Karakteristik siswa ketika mengalami kesulitan belajar antara lain : menunjukkan hasil belajar yang rendah; hasil yang dicapai tidak seimbang dengan usaha yang telah dilakukan; lambat dalam melakukan tugas-tugas kegiatan belajar, dan tidak mengerjakan PR (Lubis, 2017).

Fisika sebagai salah satu bagian dari IPA merupakan ilmu pengetahuan yang mempelajari gejala-gejala alam melalui serangkaian proses ilmiah yang dibangun atas dasar sikap ilmiah dan hasilnya terwujud sebagai produk ilmiah yag tersusun atas tiga komponen terpenting berupa konsep, prinsip, dan teori yang berlaku secara universal (Trianto,2015). Pembelajaran fisika akan lebih efektif jika melibatkan siswa siswa secara aktif dalam kegiatan pembelajaran yaitu dengan memberikan kesempatan kepada siswa untuk mengkonstruk pengetahuannya sendiri melalui pengamatan dan eksperimen. Pengalaman mengkonstruk pengetahuannya sendiri akan membuat siswa merasa makna pembelajaran yang dilakukan serta juga melatih keterampilan yang ada dari siswa.

Hasil belajar siswa SMA Negeri 1 Parbuluan juga belum terlalu baik. Hal ini dapat dilihat berdasarkan observasi bahwa masih banyak siswa yang hasil belajarnya tidak memenuhi KKM. Sebanyak $20 \%$ siswa dikelas yang bisa memenuhi KKM tanpa melalui program perbaikan dari guru. Ada banyak faktor yang menyebabkan hasil belajar siswa rendah, diantaranya kebiasaan siswa belajar hanya menerima informasi dari guru tanpa tahu apa makna informasi itu sehingga siswa merasa jenuh dalam belajar fisika, kurangnya minat untuk belajar fisika dimana hal ini terlihat ketika siswa sering mengeluh ketika akan belajar fisika, dan cara penyampaian guru dalam pembelajaran yang kurang menarik dimana guru 
lebih sering melakukan metode ceramah walaupun terkadang guru melakukan metode yang berbeda seperti demonstrasi dan diskusi.

Hasil wawancara dengan salah satu guru fisika di SMA Negeri 1 Parbuluan menyatakan pelajaran fisika sering kali dianggap siswa merupakan pelajaran yang sulit dan sangat membosankan, tidak mengherankan nilai pelajaran fisika lebih rendah dibandingkan pelajaran lain. Terlihat dari nilai rata-rata hasil ulangan harian fisika siswa di SMA Negeri 1 Parbuluan masih banyak di bawah Kriteria Ketuntasan Minimal (KKM).

Salah satu pembelajaran yang diharapkan sebagai alternatif agar siswa lebih aktif serta dapat meningkatkan berpikir kritis dan analitis aalah dengan menggunakan model pembelajaran inquiry training, rangkaian kegiatan pembelajaran ini menekankan kepada siswa agar mencari dan menemukan sendiri jawan masalah yang dipertanyakan. Model pembelajaran inquiry training adalah model pembelajaran yang diarahkan untuk membantu siswa megembangkan intelektual yang terkait dengan penalaran sehingga mampu merumuskan masalah, membangun konsep dan hipotesis serta menguji untuk mencari jawaban. Pembelajaran inkuiri merupakan kegiatan belajar yang melibatkan seluruh kemampuan siswa untuk mencari dan menyelidiki secara sistematis, kritis, logis, analitis, sehingga mereka dapat merumuskan sendiri penemuannya dengan penuh percaya diri.

Inquiry training dirancang untuk mengajak siswa secara langsung kedalam proses ilmiah melalui latihan-latihan yang meringkaskan proses ilmiah itu kedalam waktu yang relatif singkat. Inquiry training berasal dari suatu keyakinan bahwa siswa memiliki kebebasan dalam belajar. Model pembelajaran ini menuntut partisipasi aktif siswa dalam inkuiri (penyelidikan) ilmiah. Siswa memiliki keingintahuan dan ingin berkembang, dan inquiry training menekankan pada sifat-sifat siswa ini, yaitu memberikan kesempatan untuk bereksplorasi dan memberikan arah spesifik sehingga area baru dapat tereksplorasi dengan baik.

Melalui model pembelajaran inquiry training siswa dapat mengembangkan konsepnya sendiri sehingga siswa dapat mengerti tentang konsep dasar dan ide-ide lebih baik, serta mendorong siswa berfikir dan bekerja atas atas inisiatif sendiri, berfikir lebih intuitif, mengembangkan bakat dan kecepatan individu, serta dapat merumuskan hipotesisnya sendiri.

Penelitian yang relevan dengan menggunakan model pembelajaran inquiry yaitu penelitian yang dilakukan oleh Pardede dan Manurung (2016) menyatakan bahwa hasil belajar siswa yang diajarkan dengan model pembelajaran inquiry training lebih baik dari hasil belajar siswa yang diajarkan dengan model pembelajaran konvensional.

Penelitian yang dilakukan oleh Gurning dan Rahmatsyah (2017) kelas X siswa SMA Swasta RK Bintang Timur P. Siantar diperoleh Hasil penelitian menunjukkan bahwa hasil belajar Fisika dengan menggunakan model pembelajaran Inkuiri lebih baik daripada pembelajaran konvensional.

Penelitian yang dilakukan oleh Siagian dan Situmorang (2016) menyatakan hasil belajar siswa dengan model inquiry training lebih baik dari hasil belajar siswa yang diajarkan menggunakan pembelajaran konvensional.

Penelitian yang dilakukan Amdani dan Suriyadi (2015) menyatakan bahwa aktivitas pada pembelajaran dengan model inquiry training lebih aktif dari pada menggunakan pembelajaran konvensional. Hasil belajar yang Pada kelas yang menggunkan model pembelajaran inquiry training lebih tinggi dibandingakan dengan pembelajaran konvensional.

Adapun perbedaan penelitian ini dengan penelitian sebelumnya adalah tempat penelitian, sampel penelitian, waktu pelaksanaan penelitian, dan materi yang digunakan dimana pada penelitian ini menggunakan materi Elastisitas dan Hukum Hooke di SMA.

Berdasarkan uraian latar belakang masalah, peneliti akan melakukan penelitian dengan tujuan mengetahui pengaruh model inquiry training terhadap hasil belajar fisika siswa pada materi Elastisitas dan Hukum Hooke.

\section{METODE}

Bagian metode ditulis dengan panjang 15 - 
Pengaruh Model Inquiry....

$20 \%$ dari panjang artikel, berisi rancangan penelitian, teknik pengumpulan data dan sumber data serta cara analisis data. Jika kajian artikel berupa filsafat, dan teori pembelajaran, maka sub metode/ eksperimen ini tidak perlu di paparkan.

Jenis penelitian yang dilakukan adalah quasi experiment. Populasi dalam penelitian adalah seluruh siswa kelas XI SMA N 1 Parbuluan. Sampel dalam penelitian terdiri dari dua kelas yaitu kelas XI MIA-1 sebagai kelas eksperimen, dan kelas XI MIA-2 sebagai kelas kontrol yang masing-masing berjumlah 35 orang yang diambil dengan teknik cluster random sampling. Kelas eksperimen adalah kelas yang mendapat perlakuan model pembelajaran inquiry training sedangkan kelas kontrol adalah kelas yang mendapat perlakuan model pembelajaran konvensional. Untuk mengetahui hasil belajar fisika siswa dilakukan tes pada kedua kelas sebelum dan sesudah diberi perlakuan. Desain penelitian ini two group pretes - posttes dapat dilihat pada Tabel 1:

Tabel 1.Two Group Pretes - Posttes Design

\begin{tabular}{lccc}
\hline Kelas & Pre-test & Perlakuan & Post-tes \\
\hline Eksperimen & $\mathrm{X}_{1}$ & $\mathrm{~T}_{1}$ & $\mathrm{X}_{2}$ \\
\hline Kontrol & $\mathrm{X}_{1}$ & $\mathrm{~T}_{2}$ & $\mathrm{X}_{2}$ \\
\hline
\end{tabular}

Peneliti memberikan pretes pada kelas eksperimen dan kelas kontrol. Instrumen yang digunakan pada penelitian adalah. Instrumen yang terdiri dari 15 item dalam bentuk pilihan ganda dengan lima pilihan jawaban yaitu a, b, c, $\mathrm{d}$, dan e yang telah dinyatakan valid oleh tim ahli. Tes hasil belajar terlebih dahulu distandarisasi dengan menggunakan uji validitas isi oleh dua orang dosen dan satu guru sesuai dengan pakar ahlinya. Setelah data pretes diperoleh, dilakukan analisis data dengan uji normalitas yaitu uji Lilliefors, uji homogenitas dan uji kesamaan varians. Setelah itu dilakukan pengujian hipotesis uji $t$ untuk mengetahui kemampuan awal siswa pada kedua kelompok sampel dalam hal ini kemampuan awal kedua sampel tersebut harus sama. Selanjutnya peneliti mengajarkan materi pelajaran dengan menggunakan model inquiry training pada kelas eksperimen dan pembelajaran konvensional pada kelas kontrol. Perbedaan hasil akhir dapat diketahui dengan dilakukan postes menggunakan uji $\mathrm{t}$ untuk mengetahui pengaruh perlakuan model inquiry training terhadap hasil belajar siswa.

\section{HASIL DAN PEMBAHASAN}

\section{HASIL}

Hasil penelitian ini menunjukkan bahwa nilai rata-rata pretes kelas eksperimen sebesar 32,00 dan nilai rata-rata pretes kelas kontrol sebesar 28,37 . Rincian nilai pretes kelas eksperimen dan kelas kontrol dilihat pada Gambar 1.

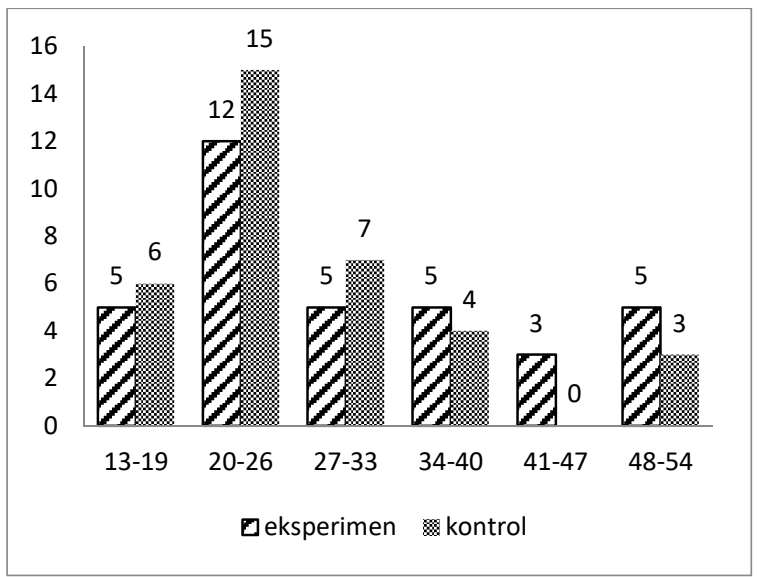

Gambar 1. Diagram Batang Data Pretes

Berdasarkan data hasil pretes siswa kelas eksperimen dan kelas kontrol, maka dilakukan terlebih dahulu uji normalitas dan uji homogenitas data pretes. Hasil perhitungan menunjukkan data pretes berdistribusi normal dan homogen maka dilakukan uji hipotesis data menggunakan uji t. Secara ringkas uji hipotesis data menggunakan uji t dapat dilihat pada Tabel 2.

Tabel 2. Ringkasan hasil Perhitungan Uji t untuk Data Pretes

\begin{tabular}{lllll}
\hline $\begin{array}{l}\text { Data } \\
\text { Pretes }\end{array}$ & $\begin{array}{l}\text { Rata- } \\
\text { rata }\end{array}$ & thitung $_{\text {nabel }}$ & $\mathbf{t}_{\text {tabel }}$ & Kesimpulan \\
\hline $\begin{array}{l}\text { Eksperi } \\
\text {-men }\end{array}$ & 32,00 & 1,25 & $1,99 \begin{array}{l}\text { Kemampuan } \\
\text { awal siswa } \\
\text { sama }\end{array}$ \\
\hline Kontrol & 28,37 & & &
\end{tabular}

Berdasarkan hasil perhitungan uji t, diperoleh thitung $<t_{\text {tabel, }}$ maka disimpulkan bahwa kemampuan awal siswa sama pada kelas eksperimen dan kelas kontrol. Langkah selanjutnya yang dilakukan oleh peneliti adalah memberikan perlakuan dengan menggunakan model pembelajaran inquiry training pada kelas eksperimen dan pembelajaran konvensional pada kelas kontrol. Setelah kedua kelas diberi perlakuan yang berbeda, kedua sampel diberikan postes untuk melihat kemampuan akhir 
Pengaruh Model Inquiry....

siswa. Hasil potes yang diperoleh ditunjukkan oleh Gambar 2. dan Gambar 3.

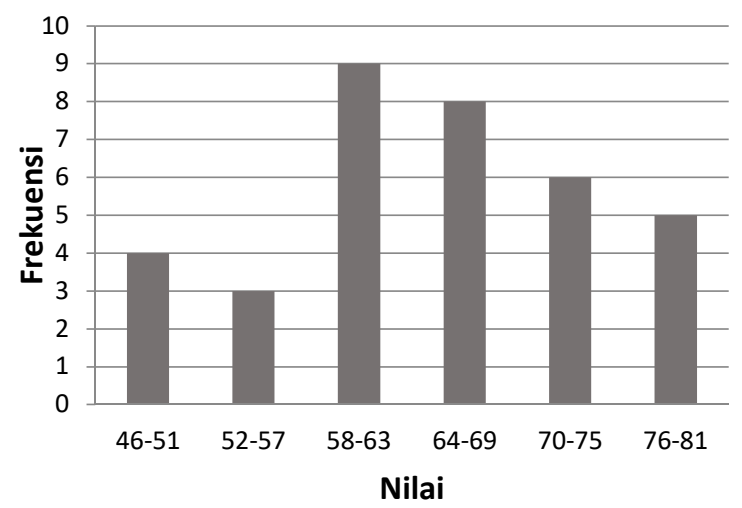

Gambar 2. Diagram Batang Data Postes Eksperimen

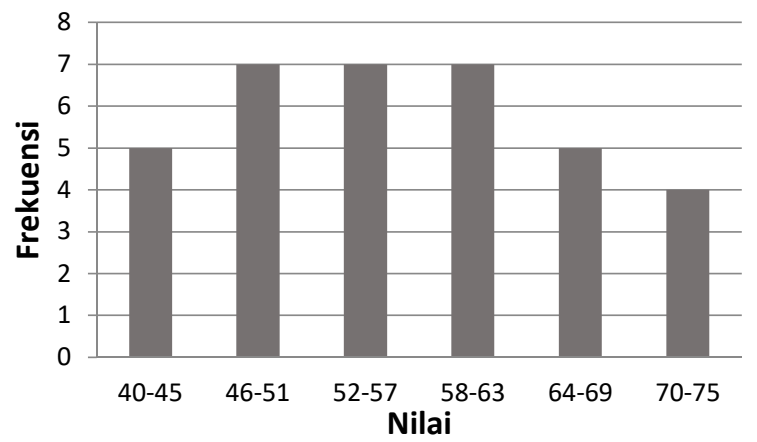

Gambar 3. Diagram Batang Data Postes Kontrol

Berdasarkan hasil postes kedua kelas, maka dilakukan terlebih dahulu uji normalitas dan uji homogenitas data postes. Hasil perhitungan menunjukkan data postes berdistribusi normal dan homogen maka dilakukan uji hipotesis data postes menggunakan uji $\mathrm{t}$ satu pihak untuk mengetahui pengaruh setelah diberikan perlakuan yang berbeda terhadap kedua kelas. Hasil yang diperoleh ditunjukkan pada Tabel 3 .

Tabel 3. Ringkasan hasil Perhitungan Uji t untuk Data Postes

\begin{tabular}{lllll}
$\begin{array}{l}\text { Data } \\
\text { Postes }\end{array}$ & $\begin{array}{l}\text { Rata- } \\
\text { rata }\end{array}$ & $\mathbf{t}_{\text {hitung }}$ & $\mathbf{t}_{\text {tabel }}$ & Kesimpulan \\
\cline { 1 - 2 } $\begin{array}{l}\text { Eksperi- } \\
\text { men }\end{array}$ & 64,57 & 3,56 & 1,669 & $\begin{array}{l}\text { Ada } \\
\text { perbedaan }\end{array}$ \\
\cline { 1 - 2 } Kontrol & 55,62 & & & \\
\hline
\end{tabular}

Berdasarkan hasil perhitungan uji t, diperoleh $t_{\text {thitung }}>t_{\text {tabel }}(3,56>1,669)$ maka dapat disimpulkan bahwa ada perbedaan akibat pengaruh dari model pembelajaran inquiry training terhadap hasil belajar fisika kelas $\mathrm{XI}$ semester I pada materi pokok Elastisitas dan Hukum Hooke di
SMA Negeri 1 Parbuluan.

Seorang observer juga melakukan pengamatan terhadap aktivitas belajar siswaberdasarkan lembar observasi selama pembelajaran berlangsung, hal ini dilakukan guna untuk melihat perkembangan aktivitas siswa di kelas eksperimen selama pembelajaran berlangsung dan diperoleh hasil seperti yang ditunjukkan pada Tabel 6.

Tabel 4. Perkembangan Aktivitas Belajar Siswa Kelas Eksperimen

\begin{tabular}{ccc}
\hline Pertemuan & $\begin{array}{c}\text { Rata-Rata } \\
\text { Aktivitas }\end{array}$ & Kriteria \\
\hline I & 55,23 & Kurang Aktif \\
\hline II & 70,85 & Aktif \\
\hline III & 82,94 & Sangat Aktif \\
\hline
\end{tabular}

\section{PEMBAHASAN}

Berdasarkan uji hipotesis hasil penelitian menunjukkan bahwa ada perbedaan akibat pengaruh yang signifikan terhadap hasil belajar siswa menggunakan model Inquiry Training pada materi Elastisitas dan Hukum Hooke di Kelas XI Semester I SMA Negeri 1 Parbuluan. Perolehan nilai rata-rata pretes siswa dikelas kontrol sebesar 28,37 dan nilai rata-rata postes sebesar 55,62, sedangkan dikelas eksperimen nilai rata-rata pretes sebesar 32,00 dan nilai ratarata postesnya 64,57 .

Selain hasil belajar dalam penelitian ini juga dilakukan pengamatan aktivitas. Nilai aktivitas rata-rata pada pertemuan pertama yaitu $55,23 \%$ termasuk dalam kategori sangat kurang baik, $\mathrm{Hal}$ ini disebabkan oleh kemungkinan siswa belum terbiasa belajar dengan model inquiry training sehingga motivasi dan pengajaran yang diberikan peneliti kurang dimengerti oleh beberapa orang siswa. Peneliti memberi arahan kepada siswa hingga siswa paham dan termotivasi dalam belajar. Pertemuan kedua yaitu $70,85 \%$ mengalami sedikit peningkatan dalam kategori kurang baik, dan pertemuan ketiga yaitu $82,94 \%$ dimana siswa sudah mulai lebih aktif dimana aktivitas siswa termasuk dalam kategori baik

Data di atas memperlihatkan bahwa peningkatan aktivitas siswa diimbangi dengan peningkatan hasil belajar siswa. Keaktifan siswa pada proses pembelajaran sangat 
mempengaruhi hasil belajar siswa. Umumnya siswa yang aktif dalam proses pembelajaran akan memiliki hasi belajar yang tinggi. Dalam penelitian ini tidak semua siswa yang aktif dalam pembelajaran memiliki hasil belajar yang tinggi dan sebaliknya. Hal ini menurut peneliti adalah hal yang wajar karena setiap individu memiliki kompetensi yang berbeda.

Perbedaan hasil belajar tersebut terjadi karena inquiry training memiliki beberapa keunggulan dimana setiap fase pada inquiry training, siswa sangat dituntut untuk berperan aktif. Ini terbukti saat penelitian pada fase yang peneliti lakukan siswa terlihat begitu antusias untuk terlibat didalamnya. Tahap pertama (menghadapkan pada masalah), peneliti menghadapkan siswa pada masalah melalui demonstrasi langsung dan penayangan video pembelajaran. Tahap kedua, ketiga dan keempat yaitu merumuskan hipotesis, merancang percobaan dan melakukan percobaan, dimana siswa merumuskan hipotesis atau memberikan jawaban sementara atas masalah yang diberikan di Lembar Kerja Peserta Didik, lalu merancang praktikum sesuai prosedur kerja yang ada di LKPD dan melakukan praktikum. Tahap yang kelima mereka mempersentasikan hasil yang mereka peroleh.

Hal ini juga relevan dengan penelitian sebelumnya seperti yang diteliti oleh : (1) Elisa (2018). Terdapat perbedaan yang signifikan antara hasil belajar siswa dengan model inquiry training dan pembelajaran konvensional pada materi pokok suhu, kalor, dan perpindahan. Berdasarkan pembahasan bahwa ada perbedaan yang signifikan jikanilai pretes, aktivitas, dan postes diurutkan bedasarkan kategorinya. (2)Gurning dan Rahmatsyah (2017) menunjukkan bahwa hasil belajar Fisika dengan menggunakan model pembelajaran inquiry training lebih baik dari pada pembelajaran konvensional. (3) Panjaitan dan Manurung (2016) menunjukkan bahwa ada pengaruh yang signifikan dari model pembelajaran inquiry training terhadap hasil belajar siswa, hal ini dibuktikan dari perolehan nilai thitung $>$ tabel. (4) Hutabarat (2017) menunjukkan bahwa ada perbedaan yang signifikan antara hasil belajar siswa dengan model inquiry training dan pembelajaran konvensional pada pengukuran.
Dalam menerapkan pembelajaran inquiry training penulis menemukan kendala dalam penelitian ini yaitu pada awal pembelajaran siswa bingung dengan penerapan model pembelajaran yang biasanya tidak diterapkan dalam proses pembelajaran di sekolah, sehingga pada pertemuan pertama siswa kurang terarah namun pada pertemuan selanjutnya siswa sudah mulai mengikuti sintaks model dengan baik. Sulitnya menguasai kelas karena siswa yang terlalu ribut ketika kerja kelompok berlangsung sehingga menghambat proses diskusi kelompok.

\section{PENUTUP}

Berdasarkan hasil penelitian yang diperoleh dari hasil analisa data dan pengujian hipotesis maka dapat disimpulkan bahwa ada perbedaan akibat pengaruh penggunaan model pembelajaran inquiry training terhadap hasil belajarfisika kelas XI semester I pada materi pokok Elastisitas dan Hukum Hooke di SMA Negeri 1 Parbuluan T.P 2019/2020.

\section{DAFTAR PUSTAKA}

Amdani, K., dan Suriyadi, A. (2015). Pengaruh Penerapan Model Pembelajaran Inquiry Training Terhadap Hasil Belajar Siswa Pada Materi Pokok Listrik Dinamis Kelas IX Semester I SMP Swasta Sabilina Tembung, Jurnal Inpafi. 3(1),112-119

Elisa, (2018). Pengaruh Model Pembelajaran inquiry training Terhadap Keterampilan Proses Sains Siswa di SMA Negeri 2 Sipirok. Jurnal penelitian dan pembelajaran MIPA, 3(1),35-41

Gurning E. S, dan Rahmatsyah, (2017), Pengaruh Model Pembelajaran Inquiry Training Pada Materi Suhu dan Kalor. Jurnal Geliga Sains, 5(2),81-87

Hutabarat, F. I (2017), Pengaruh Model Pembelajaran Inquiry Training terhadap Hasil Belajar Siswa Pada Materi Pengukuran, Jurnal Pendidikan Fisika, $6(1), 13-19$

Lubis, R. H., (2017), Pengaruh Model Pembelajaran Kooperatif Tipe Group Investigation terhadap Hasil Belajar Fisika Siswa Ditinjau dari Adversity 
Quotient Siswa, Jurnal Pendidikan Fisika, 6(1),44-49

Panjaitan, M.D.C dan Manurung, S.R. (2016). Pengaruh Model Pembelajaran Inquiry Training Berbantuan Macro Media Flash Terhadap Hasil Belajar Siswa di Kelas XI SMA Negeri 10 Medan T.P 2014/2015. Jurnal Inpafi, 4(1),77-85

Pardede, D. M. dan Manurung, S. R. (2016). Pengaruh Model Pembelajaran Inquiry Training dan Motivasi Terhadap Hasil Belajar Fisika Siswa, Jurnal Pendidikan Fisika. 5(1),1-6

Sanjaya, W. (2011). Strategi Pembelajaran: Berorientasi Standar Proses Pendidikan. Jakarta: Kencana

Siagian, H. Dan Situmorang, R. A. (2016). Pengaruh Model Pembelajaran Terhadap Hasil Belajar Siswa Pada Materi Pokok Listrik Dinamis Inquiry Training, Jurnal Inpafi.4(1),39-46

Trianto.(2015). Mendesain Model Pembelajaran Inovatif, Progresif, dan Kontekstual. Jakarta: Kencana

Wahyuni, I., dan Sipapaga,D. S. (2015). Pengaruh Model Pembelajaran Inquiry Training terhadap Hasil Belajar Siswa pada Materi Pokok Listrik dinamis, Jurnal Ikatan Alumni Fisika Universitas Negeri Medan, 1(1), 22-28 